\title{
KAJIAN HUKUM TENTANG PENEGAKAN HUKUM TERHADAP PENAMBANGAN DI TAMAN HUTAN RAYA BUKIT SOHARTO
}

Oleh :

H. Saripudin

Dosen Fakultas Hukum Universitas Widya Gama Mahakam Samarinda

\begin{abstract}
ABSTRAK
Kawasan Bukit Soeharto termasuk dalam kawasan hutan lindung berdasarkan Keputusan Menteri Pertanian Nomor 818/KPTS/UM/1982, sedangkan untuk menambang di hutan lindung pemerintah mengeluarkan Peraturan Menteri Kehutanan Nomor 55/KPTS II/1994, ini berlaku sejak 7 Februari yang seterusnya direvisi kembali dengan Peraturan Menteri Kehutanan Nomor P 43/Menhut-II/2008.

Berlakunya ijin kuasa penambangan dieluarkan oleh pemerintah Kabupaten Kutai Kartanegara, dan juga memberikan ijin pinjam pakai kawasan konservasi Bukit Soeharto yang tentu bermasalah ketika terjadi perubahan luas taman hutan raya tersebut dan berdampak kepada kebijakan yang dibuat oleh Pemerintah Kabupaten Kutai Kartanegara dalam pemberian Kuasa Pertambangan.
\end{abstract}

Kata Kunci :Penegakan Hukum, Penambangan

\section{PENDAHULUAN}

Pembangunan nasional di Indonesia harus dilaksanakan dengan prinsip kemandirian. Mengenai prinsip kemandirian dalam pembangunan nasional tersebut dapat dilihat pada Pasal 33 ayat (4) UUD 1945 yang berbunyi :

"Perekonomian nasional diselenggarakan berdasarkan atas asas demokrasi ekonomi dengan prinsip kebersamaan, berwawasan lingkungan, kemandirian, serta dengan menjaga keseimbangan kemajuan dan kesatuan ekonomi nasional".

Dengan prinsip kemandirian dalam pembangunan nasional dimaksudkan bahwa pembangunan yang dilaksanakan dari waktu kewaktu sedapat mungkin akan dibiayai dengan dana yang dimiliki oleh bangsa Indonesia sendiri.

Dana untuk membiayai pembangunan nasional dapat bersumber baik dari sector pemerintah maupun dari sector swasta. Pemerintah membiayai pembangunan nasional dari sumber-sumber yang dimilikinya, yang sebagian besar berasal dari tabungan pemerintah. Tabungan pemerintah terbentuk dari penerimaan-penerimaan Negara yang diperoleh dari hasil pemungutan pajak, penerimaan non pajak maupun penerimaan jenis lainnya. Di pihak lain, dana yang dipergunakan oleh sektor swasta. Bersumber dari Tabunganyang dihimpun oleh sektor swasta. Tabungan sektro swasta diperoleh dari selisih pendapatan rumah tangga/ perorangan setelah dikurangi dengan konsumsi. Sektro swasta juga dapat berbentuk badan usaha/ perusahaan yang memiliki tabungan untuk membiayai kegiatan usahanya, tabungan yang bersumber 
dari selisih penerimaan perusahaan setelah dikurangi dengan pengeluaranpengeluaran operasionalnya.

Karena dana yang diperlukan untuk membiayai kebutuhan pembangunan nasional cukup besar, sedangkan dilain pihak dana yang dimiliki pemerintah relative terbatas, kegiatan pembangunan tidak mungkin seluruhnya dilaksanakan dan dibiayai oleh pemerintah. Untuk hal tersebut pemerintah menggandeng sektor swasta untuk membiayaan pembangunan tersebut. ${ }^{1}$

Swasta didalam turut serta didalam pembangunan mempunyai perhitungan untung dan rugia dalam artian swasta ddidalam mengnvestasikan tabungannya pertimbangan segi ekonomi lebih diutamakan apakah itu menguntungkan atau tidak. Pemerintah ,menyadari akan hal ini salah satu cara adalah dengan memanfaatkan sumber daya alam yang di kuasai oleh Pemerintah berdasarkan Pasal 33 ayat 3 UUD 1945.

Salah satu sumber daya alam yang menarik perhatian investor adalah batu bara yang terdapat di hutan lindung bukit bukit soharto dimana menurut hasil survey terdapat lebih dari 122-150 juta metric ton batu bara dibukit Suharto yang siap untuk di tambang dan hal ini tentunya sangat menggiurkan pihak swasta untuk menambang batu bara tersebut.

Oleh karena kawasan bukti soharto termasuk didalam kawasan hutan lindung berdasarkan keputusan Menteri pertanian nomor $818 / \mathrm{Kpts} / \mathrm{Um} / 1 / 1982$ tentang penetapan hutan lindung bukit Suharto $27.000 \mathrm{Ha}$. ditindak lanjuti dengan surat Keputusan Menteri Kehutanan nomor 245/Kpts-II/1987 tanggal 18 agustus 1987; perubahan status kawasan hutan lindung Bukit Suharto sekitar 23.800 Ha menjadi hutan wisata dan menunjukan perluasannya dengan kawasan hutan sekitarnya seluas kurang lebih 41.050 Ha sehingga luas hutan wisata Bukit Suharto kurang lebih 64.850 Ha. $^{2}$

Untuk menambang di hutan lindung pemerintah mengeluarkan Peraturan Menteri kehutanan No. 55/kpts-II/1994 ini berlaku sejak 7 pebruari 1994. Yang kemudian direvisi dengan Peraturan Menteri Kehutanan 14/Menhut-II/2006 dan direvisi kembali dengan peraturan menteri kehutanan No. P.43/Menhut-II/2008.

Tapi berdasarkan data yang dihimpun oleh Gubernur Kaltim ada 52 perusahaan yang mendapat ijin KP (kuasa penambangan) dari Pemkab Kutai Kartenegara. Ke-52 perusahaan itu kini dalam proses melengkapi berbagai administrasi, eksplorasi dan bahkan ternyata sudah ada yang melakukan eksploitasi dan produksi. Berdasarkan data yang ada di tangan Awang Faroek Ishak teamnya pihak yang mengeluarkan ijin KP adalah Pemerintah Kabupaten Kutai Kartanegara. ironisnya, ada sebuah perusahaan yang telah mendapat ijin pinjam pakai kawasan konservasi itu. ${ }^{3}$ Hal ini juga membuat Menteri kehutanan berang yang mengakibatkan ada 3 perusahaan yang diperiksa. Berdasarkan hal tersebut penelitian hukum ini mengangkat judul " KAJIAN HUKUM TENTANG PENEGAKAN HUKUM TERHADAP PENAMBANGAN DI TAMAN HUTAN RAYA BUKIT SOHARTO”.

\footnotetext{
${ }^{1}$ DR.Jonker Sihombing ,SE.,M.A.,M.H. Hukum Penanaman Modal, Alumni , Bdng, hlm. 27.

${ }^{2}$ BataViase.co.id. bukit soeharto "Etalase " hutan lestari yang sekarat.

${ }^{3}$ Tempointraktif.Com, pertambangan di hutan lindung dipermudah.
} 


\section{RUMUSAN MASALAH}

Berdasarkan dari latar belakang diatas dapat rumuskan adanya pemasalah sebagai berikut :

1. Bagaimana penegakan hukum terhadap kasus penambangan di Taman Hutan Raya Bukit Soeharto?

2. Kendala-kendala apa yang dihadapi aparat penegak hukum di dalam penegakan hukum tersebut?

\section{MAKSUD DAN TUJUAN}

1. Maksud dari pada penelitian hukum ini adalah :

a. Untuk mengetahui bagaimana penegakan hukum terhadap kasus illegal mining di hutan taman hutan raya bukit Soeharto

b. Untuk mengetahui kendala-kendala apa yang dihadapi aparat penegak hukum di dalam penegakan hukum tersebut.

2. Tujuan dari penelitian ini adalah :

a. Sebagai bahan masukkan bagi instansi dan para pihak yang tertkait yang berhubungan dengan penegakan hukum khususnya di taman hutan raya bukit Soeharto

b. Sebagai bahan masukan bagi pemerintah Pusat, Provinsi dan kabupaten di dalam membuat kebijakan pertambangan di hutan lindung.

\section{METODE PENELITIAN}

Di dalam penelitian ini penulis mengunakan metode normatif dengan data sebagai berikut

1. Bahan Hukum atau sumber Data

a. Bahan Hukum primer penelitian hukum ini adalah :

1) Undang-Undang Nomor 41 Tahun 1999 Tentang Kehutanan.

2) Peraturan Pemerintah Pengganti Undang-Undang No. 1/ 2004

3) Undang-Undang Nomor : 4 Tahun 2009 tentang Pertambangan mineral dan batu bara.

4) Peraturan Menteri Kehutanan Nomor P.14/Menhut-II/2006 tentang Pedoman Pinjam Pakai kawasan Hutan.

5) Surat keputusan Menteri Kehutanan No. 419/Menhut-II/2004 tentang penetapan tahura Bukit Soeharto.

6) Keputusan Menteri kehutanan No. 577/Menhut-II/2009 tentang penetapan Kawasan Hutan bukit Soeharto.

7) Surat Dirjen PHKA nomor S.467/IV-KK/2007 tanggal 11 Juli 2007 tentang memberikan ijin kepada perusahaan tambang untuk menggunakan jalan di dalam kawasan tahura Bukit Soeharto.

8) Surat Gubernur Kalimantan Timur No. 521/7494/EK, tgl 14 Agustus 2009 dan 521/1875/Ek tanggal 2 Maret 2009. 
b. Bahan Hukum Sekunder penelitian ini adalah bahan yang memberikan penjelasan mengenai bahan hukum primer, seperti Makalah-makalah hasil seminar tentang kegiatan pertambangan batu bara di wilayah samarinda dan literatur-literatur di bidang hukum.

c. Bahan Hukum Tersier, yaitu bahan yang memberikan petunjuk atau penjelasan terhadap bahan hukum primer dan bahan hukum sekunder, seperti Kamus (hukum) dan ensiklopedia.

\section{TINJAUAN PUSTAKA}

\section{Pengertian Hutan}

Pasal 1 dalam Undang-Undang ini yang dimaksud dengan :

1. Kehutanan adalah sistem pengurusan yang bersangkut paut dengan hutan, kawasan hutan, dan hasil hutan yang diselenggarakan secara terpadu.

2. Hutan adalah suatu kesatuan ekosistem berupa hamparan lahan berisi sumber daya alam hayati yang didominasi pepohonan dalam persekutuan alam lingkungannya, yang satu dengan lainnya tidak dapat dipisahkan.

3. Kawasan hutan adalah wilayah tertentu yang ditunjuk dan atau ditetapkan oleh Pemerintah untuk dipertahankan keberadaannya sebagai hutan tetap.

Hukum kehutanan adalah himpunan peraturan bidang kehutanan yang tertulis maupun tidak tertulis yang memberikan sanksi kepada pelanggarnya, dan mengatur hubungan antara pengelola hutan, pengguna hutan dan hasil hutan beserta kekayaan alam yang terkandung didalamnya dengan memperhatikan konservasi sumber daya alam hayati dan ekosistemnya. ${ }^{4}$

Pengertian Kehutanan menurut UUPK No. 41 Tahun 1999 ialah sistem pengurusan yang bersangkut paut dengan hutan, kawasan hutan, dan hasil hutan yang diselenggarakan secara terpadu.

\section{Hubungan Antara Negara Dengan Hutan}

Di dalam Pasal 33 ayat (3) Undang-Undang Dasar 1945 disebutkan bahwa : "Bumi dan air dan kekayaan alam yang terkandung di dalamnya dikuasai oleh negara dan dipergunakan untuk sebesar-besarnya kemakmuran rakyat."

Pengertian dikuasai bukan berarti dimiliki, melainkan suatu pengertian yang mengandung kewajiban dan wewenang dalam hukum publik.

Hak negara dalam bidang kehutanan adalah berwenang untuk : (1) menetapkan dan mengatur perencanaan, peruntukan, penyediaan, dan penggunaan hutan sesuai dengan fungsinya dalam memberikan manfaat kepada rakyat dan negara, (2) mengatur pengurusan hutan dalam arti luas, (3) menentukan dan mengatur hubungan-hubungan hukum antara

4 Bahan Materi Kuliah Hukum Kehutanan, semester VI, Dosen Pengajar Nainuri Suhadi, SH 
orang atau badan hukum dengan hutan dan mengatur perbuatan-perbuatan hukum mengenai hutan (Pasal 5 Undang-Undang Nomor 5 Tahun 1967).

Dalam Pasal 4 UU Nomor 41 Tahun 1999 disebutkan tentang hak negara atas hutan. Di dalam pasal itu ditentukan semua hutan di dalam wilayah Republik Indonesia termasuk kekayaan alam yang terkandung di dalamnya dikuasai oleh negara untuk sebesar-besar kemakmuran rakyat. Maksud penguasaan hutan oleh negara adalah memberikan wewenang kepada Pemerintah untuk :

1. Mengatur dan mengurus segala sesuatu yang berkaitan dengan hutan, kawasan hutan, dan hasil;

2. Menetapkan status wilayah tertentu sebagai kawasan hutan atau bukan kawasan hutan;

3. Mengatur dan menetapkan hubungan-hubungan hukum antara orang dengan hutan, serta mengatur perbuatan-perbuatan hukum mengenai kehutanan.

Penguasaan itu tetap memperhatikan hak masyarakat hukum adat, sepanjang kenyataannya masih ada dan diakui kebenarannya, serta tidak bertentangan dengan kepentingan nasional.

Selain itu, Pemerintah juga mempunyai wewenang untuk memberikan izin dan hak kepada pihak lain untuk melakukan kegiatan di bidang kehutanan. Namun demikian, untuk hal-hal tertentu yang sangat penting, berskala, dan berdampak luas serta bernilai strategis, Pemerintah harus memperhatikan aspirasi rakyat melalui persetujuan Dewan Perwakilan rakyat. 5

\section{Asas Hukum Kehutanan}

Hukum kehutanan berasaskan manfaat dan lestari, kerakyatan dan keadilan, kebersamaan, keterbukaan, dan keterpaduan (Pasal 2 Undang-Undang Nomor 41 Tahun 1999 tentang Kehutanan). Maksudnya manfaat dan lestari - agar pengurusan kehutanan memperhatikan adanya keseimbangan dan kelestarian unsur lingkungan, sosial, dan budaya, serta ekonomi; kerakyatan dan keadilan - agar pengurus kehutanan harus memberikan peluang dan kesempatan yang sama kepada semua warga negara sesuai dengan kemampuannya, sehingga dapat meningkatkan kemakmuran seluruh rakyat; kebersamaan - agar pengurus kehutanan menerapkan pola usaha bersama sehingga terjalin saling keterkaitan dan kebergantungan secara sinergis antara masyarakat setempat dan Badan Usaha Milik Negara (BUMN) atau Badan Usaha Milik Daerah (BUMD), dan Badan Usaha Milik Swasta (BUMS) Indonesia, dalam rangka pemberdayaan usaha kecil, menengah, dan koperasi; keterbukaan - agar pengurusan kehutanan dilakukan secara terpadu dengan memperhatikan kepentingan nasional, sektor lain, dan masyarakat setempat.

H. Salim, H.S., S.H., M.S. “DASAR-DASAR HUKUM KEHUTANAN”, Penerbit Sinar Grafika, Jakarta 2008, Hal. 12-13. 


\section{Istilah dan Pengertian Hukum Pertambangan}

Istilah hukum pertambangan merupakan terjemahan dari bahasa Inggris, yaitu mining law. Hukum pertambangan adalah : "hukum yang mengatur tentang penggalian atau pertambangan bijih-bijih dan mineral-mineral dalam tanah" 6

Definisi ini hanya difokuskan pada aktivitas penggalian atau pertambangan bijih-bijih. Penggalian atau pertambangan merupakan usaha untuk menggali berbagai potensi-potensi yang terkandung dalam perut bumi. Didalam definisi ini juga tidak terlihat bagaimana hubungan antara pemerintah dengan subyek hukum. Padahal untuk menggali bahan tambang itu diperlukan perusahaan atau badan hukum yang mengelolanya.

Pengertian Pertambangan menurut Undang-undang No. 4 Tahun 2009 tentang Pertambangan Mineral dan Batubara, Pasal 1 Ayat (1) Pertambangan adalah sebagian atau seluruh tahapan kegiatan dalam rangka penelitian, pengelolaan dan pengusahaan mineral atau batubara yang meliputi penyelidikan umum, eksplorasi, studi kelayakan, konstruksi, penambangan, pengolahan dan pemurnian, pengangkutan dan penjualan, serta kegiatan pascatambang, Ayat (6) Usaha Pertambangan adalah kegiatan dalam rangka pengusahaan mineral atau batubara yang meliputi tahapan kegiatan penyelidikan umum, eksplorasi, studi kelayakan, konstruksi, penambangan, pengolahan dan pemurnian, pengangkutan dan penjualan, serta pascatambang, dan Ayat (19) Penambangan adalah bagian kegiatan usaha pertambangan untuk memproduksi mineral dan/atau batubara dan mineral ikutannya. ${ }^{7}$

\section{Sejarah Bukit Soeharto}

Kawasan Taman Hutan Raya Bukit Soeharto secara geografis terletak antara 1 Lintang Selatan dan 117 Bujur Timur. Secara administratif pemerintahan termasuk Kelurahan Sie Merdeka, Kecamatan Semboja, Kotamadya Samarinda, Propinsi Kalimantan Timur.

Taman Wisata Alam Bukit Soeharto memiliki beberapa tipe ekosistem antara lain, hutan campuran Dipterocarpaceae dataran rendah, hutan kerangas, hutan pantai, semak belukar dan alang-alang. Luas wilayah bukit soeharto sekitar 61.000 Ha. Di antara kawasan itu terdapat bumi perkemahan yang indah karena terdapat kolam dan pondokpondok, serta terdapat zona kawasan hutan lindung serta hutan penelitian Universitas Mulawarman.

Secara umum keadaan topografi lapangan Taman Wisata Alam Bukit Soeharto bervariasi dari bergelombang ringan sampai berbukit terjal dengan tingkat kemiringan 3 sampai dengan $30 \%$.

Berdasarkan klasifikasi Schmidt dan Ferguson Taman Wisata Alam Bukit Soeharto termasuk ke dalam klasifikasi type A dengan curah hujan berkisar antara $2.000 \mathrm{~mm}$ sampai

\footnotetext{
6 H. Salim HS., S.H., M.S. "HUKUM PERTAMBANGAN DI INDONESIA", Penerbit PT Raja Grafindo Persada, Jakarta 2005 Hal. 7.

7 “Undang-Undang Di Bidang Pertambangan” Penerbit CV. Eko Jaya, Jakarta, Cet. Pertama 2009, Hal 4
} 
$2.500 \mathrm{~mm} /$ tahun. Kondisi suhu berkisar antara $20^{\circ} \mathrm{C}-30^{\circ} \mathrm{C}$, dengan kelembaban rata-rata $67-95 \%$.

Selama dua tahun berjalan telah tercatat ada 30 jenis mamalia yang ditemukan di kawasan ini, termasuk yang terakhir didapat gambar dari kamera otomatis (camera trap) jenis kucing kuwuk (Felis bengalensis). Informasi lain menyebutkan ditemukannya orangutan (Pongo pygmaeus) di kawasan ini, yang sebelumnya tidak pernah tercatat ada.

Taman Hutan Raya Bukit Soeharto merupakan tempat sebaran beberapa jenis fauna antara lain : Orang utan (Pongo pygmaeus), terdapat di fasilitas rehabilitasi orang utan di Pusat reintroduksi Orang Utan Wanariset Samboja, Beruang madu (Helarctos malayanus), Macan Dahan (Neofelis nebulosa), Landak (Hystrix brachyura), kucing kuwuk (Felis bengalensis), Babi hutan (Sus sp.), Kancil (Tragullus sp.), Kera (Macaca fascicularis) dan lain-lain.

Dalam daftar jenis mamalia kalimantan hanya ditemukan 5 jenis kucing- kucingan yang masuk dalam ordo carnivora. Yang paling besar dari kelompok jenis ini adalah macan dahan (Neofelis nebulosa), sisanya adalah jenis kucing- kucingan yang memiliki ukuran tubuh lebih kecil. Kucing kuwuk berwarna bungalan kemerahan atau kekuningan dengan bintik-bintik hitam di seluruh tubuh bagian atas termasuk ekor. Biasanya nokturnal dan terestrial, tetapi kadang aktif di pepohonan kecil. Makanannya meliputi mamalia kecil dan serangga besar. Biasa terdapat di hutan dan perkebunan sekitar hutan.

\section{PEMBAHASAN}

Masalah pertambangan di kawasan sekitar hutan lindung bukit soharto adalah masalah yang sangat penting banyak kepentingan yang ikut bermain didalam hal mengincar deposit batu bara yang ada di kawasan hutan lindung bukit soharto tersebut.

Keberadaan bukit soharto sendiri sebagai paru-paru dunia mempunyai peran yang sangat penting dalam hal perlindungan ekelogi lingkungan didalam hutan raya tersebut banyak ditemui tumbuh-tumbuhan dan prinata yang sangat langka yang hanya hidup di hutan tropis, oleh karena itu keberadaannya harus terus dijaga dan dilindungi.

Terbutnya sk menteri no 577/ MENHUT-II/2009 sangat kita sambut dengan baik, tujuannyaa adalah untuk memberikan kepastian hukum tentang penetapan kawasan taman hutan raya Bukit soeharto baik secara obyek atau tanahnya maupun usaha Negara legalitas kawasan tersebut. Namun yang kita sayangkan adalah cara penetapan kawasan tersebut yang menurut hemat tim penulis adalah bermasalah seharusnya didalam penetapan kawasan apalagi jika kawasan dikelilingi oleh kawasan pertambangan akan banyak kepentingan yang harus diperhatikan akibat dampak dari lahirnya surat keputusan tersebut.

Seharusnya menurut hemat tim penulis Menteri kehutanan didalam penetapan kawasan tersebut seharusnya berkoordinasi dengan daerah yang kawasannya termasuk

didaerah Taman hutan raya bukit Soeharto.sehingga tidak terjadi benturan kepentingan didalam penetapan kawasan tersebut dengan kebijakan daerah didalam mengeskloitasi sumber daya alam yang tidak termasuk kawasan tersebut menurut Surat keputusan Nomor 270/ Kpts-II/1991 tanggal 20 mei 1991 tetapi dengan terbitnya Sk 577 menjadi daerah kawasan taman hutan raya hal ini tentunya ada menimbulkan masalah atau benturan 
dengan undang-undang kehutanan, karena menurut ketentuan undang_Undang kehutanan kawasan yang bisa dieksloitasi sumber daya alam diluar hutan adalah hutan produksi dengan cara pinjam pakai, berkaitan dengan taman hutan raya itu sama sekali tidak boleh dieksloitasi sehingga jika di SK 577 maka dictum ke empatnya mengakomodir kebijakan yang dibuat oleh daerah maka surat keputusan tersebut bertentangan dengan Undang_undang No. 10 tahun 2004 tentang pembentukan peraturan perundangUndangan. Apalagi Surat keputusan tidak termasuk dalam daftar peraturan perundangundangan sehingga surat keputusan tersebut harusnya dibatalkan.

Surat keputusan juga bukan produk hukum yang sifatnya mengikat secara umum jika kita lihat difinisi surat keputusan menurut Undang-Undang No. 5 tahun 1986 Jo. Undang-undang No. 9 tahun 2004 pada bab I ketentuan umum bagian pertama pengertian Pasal I angka 3 menyatakan keputusan tata usaha Negara adalah suatu penetapan tertulis yang dikeluarkan oleh badan atau Pejabat tatausaha Negara yang berisi tindakan hukum tata usaha Negara yang berdasarkan peraturan perundang-Undangan yang berlaku, yang bersifat konkrit, individual dan final yang menimbulkan akibat hukum bagi seseorang atau badan hukum.

Jika kita membaca difinisi yang diberikan oleh undang-Undang ini yang termasuk surat keputusan memerlukan 3 ciri yaitu konkrit, individual dan final. Dari ketiga ciri ini jika kita sandingkan dengan surat keputusan menteri kehutanan maka ketiga ciri tersebut maka tidak ada satupun memeiliki kualifikasi Sebagai surat keputusan, maka berdasarkan hal tersebut menurut hemat tim penulis Surat keputusan tersebut tidak sah dan harus dibatalkan.

Akibat penerbitan tanpa ada kordinasi dengan pihak-pihak yang terkait, hal ini bagaikan buah simalakama, bagi pihak Kemeterian kehutanan, jika pihak kementerian kehutanan membatalkan atau menyatakan surat keputusan Bupati tidak sah tidak logis didalam logika hukum surat keputusan mencabut surat keputusan walaupun sama-sama surat keputusan tapi instutusi yang mengeluarkan berbeda yang satu pemerintah daerah dan yang satunya adalah kementerian kehutanan kalaupun bisa seharusnya yang membatalkan surat keputusan tersebutb adalah institusi yang mengeluarkan surat keputusan tersebut pada selain itu jika pihak Kementrian kehutanan juga akan di PTUN oleh pihak-pihak yang merasa dirugikan dengan terbitnya surat keputusan yang menyatakan Kuasa pertambangan yang diterbitkan Bupati dicabut tersebut, jika Menteri mengakomodir sebagaimana saat sekarang ini, itu diluar kopetensi dirinya.

Menurut hemat penulis penetapan kawasan taman hutan raya Bukit Soeharto seharusnya dengan penetapan pemerintah, selain aturan itu memang ada didalam tataurutan peraturan perundang-undangan sebagai pelaksanaan dari undang-undang kehutanan dan juga jika ada perubahan terhadap kawasan itu tidak mudah, karena tidak ditentukan oleh satu organ atau Kementerian. Selain itu dengan ditetapkannya tersebut dengan peraturan pemerintah maka dengan sendirinya Surat keputusan bupati yang memberikan kuasa pertambangan kepada para pengusaha disekitar kawasan taman hutan raya dengan sendirinya akan gugur karena bertentangan dengan peraturan yang lebih tinggi yaitu Peraturan pemerintah.

Selain itu yang harus diperhatikan oleh adalah tenaga pengawas kegiatan pertambangan tersebut, menurut data yang didapat di Dinas Pertambangan kutai mereka hanya mempunyai tenaga Inspektur Tambang hanya 18 personil saja dengan rincian 
sarjana tambang 6 orang, jumlah tenaga ahli bidang geologi 1 orang, sarjana ahli bidang geodesi 1 orang, sarjana di bidang Non Teknis 1 orang dan 9 orang bidang non teknis. Dari jumlah tenaga yang sebanyak ini suatu hal yang tidak mungkin bisa mengawasi lokasi tambang yang sangat luas, apa lagi tidak didukung oleh sarana dan prasarana yang tidak memadai sehingga sangat tidak mungkin bisa mengamankan atau mengawasi perusahaan-perusahaan tambang yang beroperasi dikawasan sekitar taman hutan raya bukit soharto tidak melakukan pelanggaran terhadap kawasan hutan raya tersebut.

\section{PENUTUP}

\section{A. Kesimpulan}

1. Bahwa salah satu penyebab terjadinya penambangan batu bara di hutan raya Bukit Soeharto adalah adanya SK 577/menhut-II/2009 tictum keempat huruf b yang mengakomodir penambangan batu bara yang dizin Kuasa pertambangan dikeluarkan oleh bupati.

2. Bahwa didalam penegakan hukum pengawasan penambangan dihutan raya bukit soeharto sangat lemah karena tidak didukunG oleh perangkat peraturan, personalia, sarana dan prasarana yang memadai.

\section{B. Saran-saran}

1. Perlunya mencabut dictum keempat huruf b Sk 577/menhut-II//2009.

2. Pemerintah daerah tidak hanya bisa memberikan izin eksploitasi kepada pengusaha tetapi juga harus menyiapkan SDM , sarana dan prasarana yang memadai didalam pengawasan SDA tersebut.

\section{DAFTAR PUSTAKA}

\section{BUKU-BUKU :}

Agus Haryanta, Informasi Kawasan Konservasi Kalimantan Timur, BKSD Kalimantan Timur, Samarinda, 2004.

Abdul Khakim, S.H., "PENGANTAR HUKUM KEHUTANAN INDONESIA", Penerbit PT. Citra Aditya Bakti, Bandung 2005.

Bambang Sunggono, S.H., M.S. "Metodologi Penelitian Hukum", Penerbit PT. Raja Grafindo Persada, Jakarta 2007

Dekdikbud, Kamus Besar Bahasa Indonesia, Penerbit Balai Pustaka, Jakarta

H. Salim, H.S., S.H., M.S. "DASAR-DASAR HUKUM KEHUTANAN”, Penerbit Sinar Grafika, Jakarta 2008. 
"Hukum Pertambangan Di Indonesia", Penerbit PT. Raja Grafindo Persada, Jakarta 2005.

Nasution. MA. Prof., Dr,. S dan Thomas., Prof Dr., M. , Buku Penuntut Membuat Tesis, Skripsi, Dsertasi, Makalah, Bumi Aksara, Jakarta 1999

Soerjono Soekanto., SH., MA., Dr., Tata Cara Penyusunan Karya Tulis ilmiah Bidang Hukum. Ghalia Indonesia, Jakarta, 1993.

Sutrisno Hadi., MA. Prof., Dr., Bimbingan Menulis Skripsi Thesis 1., Andi Offset, Yogyakarta, 1998.

Salim HS., S.H., M.S. “Hukum Pertambangan Di Indonesia”, Penerbit PT. Raja Grafindo Persada, Jakarta 2005.

.WFriedman, Teori dan Filsafat hokum, filosofis dan Problema Keadila, Rajawali pers, 1990

\section{PERUNDANG-UNDANGAN :}

-------, Undang-Undang Dasar Republik Indonesia 1945

Himpunan Peraturan Perundang-undangan Republik Indonesia tentang "KEHUTANAN DAN ILLEGAL LOGGING”, Penerbit Nuansa Aulia, Bandung 2008

"Undang-Undang Di Bidang Pertambangan" Penerbit CV. Eko Jaya, Jakarta, Cet. Pertama 2009

-------, PP RI No. 75 Tahun 2001 tentang Ketentuan-Ketentuan Pokok Pertambangan

-------, PP RI No. 23 Tahun 2010 tentang Pelaksanaan Kegiatan Usaha Pertambangan Mineral dan Batu Bara

-------, Keputusan Menteri Kehutanan NOMOR : SK.270/Kpts-II/1991

-------, Keputusan Menteri Kehutanan NOMOR : SK.79/Menhut-II/2001

-------, Keputusan Menteri Kehutanan NOMOR : SK.577/Menhut-II/2009

-------, Keputusan Menteri Kehutanan NOMOR : SK.419/Menhut-II/2004 